\title{
Nephrotic Syndrome: Is HIV Associated Nephropathy on Your Differential?
}

\author{
Jad Al Danaf, MD \\ Thomas Jefferson University, jad.danaf@jefferson.edu \\ Jeffrey Marbach, MD \\ Thomas Jefferson University, jeffrey.marbach@jefferson.edu \\ Sharon Li, MS4 \\ Thomas Jefferson University, sharon.li@jefferson.edu \\ Emily Stewart, MD \\ Thomas Jefferson University, Emily.stewart@jefferson.edu
}

Follow this and additional works at: https://jdc.jefferson.edu/tmf

Part of the Medicine and Health Sciences Commons

Let us know how access to this document benefits you

\section{Recommended Citation \\ Danaf, MD, Jad Al; Marbach, MD, Jeffrey; Li, MS4, Sharon; and Stewart, MD, Emily (2015) "Nephrotic Syndrome: Is HIV Associated Nephropathy on Your Differential?," The Medicine Forum: Vol. 16 , Article 10. DOI: https://doi.org/10.29046/TMF.016.1.009 \\ Available at: https://jdc.jefferson.edu/tmf/vol16/iss1/10}

This Article is brought to you for free and open access by the Jefferson Digital Commons. The Jefferson Digital Commons is a service of Thomas Jefferson University's Center for Teaching and Learning (CTL). The Commons is a showcase for Jefferson books and journals, peer-reviewed scholarly publications, unique historical collections from the University archives, and teaching tools. The Jefferson Digital Commons allows researchers and interested readers anywhere in the world to learn about and keep up to date with Jefferson scholarship. This article has been accepted for inclusion in The Medicine Forum by an authorized administrator of the Jefferson Digital Commons. For more information, please contact: JeffersonDigitalCommons@jefferson.edu. 


\title{
Nephrotic Syndrome: Is HIV Associated Nephropathy on Your Differential?
}

\author{
Jad Al Danaf, MD, Jeffrey Marbach, MD, Sharon Li, MS4, Emily Stewart, MD
}

\section{CASE DESCRIPTION}

A 30-year old African American female with no significant past medical history initially presented to our emergency department with three days of sore throat, dysphagia, fever, fatigue, nausea and vomiting. She denied ear pain, rhinorrhea, shortness of breath or any sick contacts. Her social history was negative for tobacco, alcohol and illicit drug use. She works as a security officer, lives with her family and is sexually active only with her husband. On initial examination she was febrile to $101.9^{\circ} \mathrm{F}$, with a heart rate of 100 beats per minute, blood pressure of 143/99 $\mathrm{mmHg}$, respiratory rate of 18 breaths per minute and an oxygen saturation of $99 \%$ on room air. Her only pertinent physical examination findings were a mildly erythematous oropharynx without exudates, mildly swollen uvula and right tonsil, bilateral tender swollen sub-mandibular lymph nodes and reduced breath sounds on auscultation of the right lower lung base.She was routinely tested for HIV, ruled out for group A strep, and discharged home with the diagnosis of viral pharyngitis on supportive care.

Following the identification of a presumptive positive rapid HIV screening test with evidence of HIV-1 p24 antigen and a reactive HIV-1 antibody on the multispot HIV 1 / 2 antibody test she was called to return to the ED for counseling regarding a positive HIV test. She reported continuation of her prior symptoms with worsening dysphagia, as well as new complaints of bilateral lower extremity edema to the knees. Initial laboratory testing revealed an elevated serum creatinine $(\mathrm{Cr})$ of $2.2 \mathrm{mg} / \mathrm{dL}$ (0.7-1.3 mg/dL) up from $<1.0 \mathrm{mg} / \mathrm{dL}$ one-year prior, with an estimated Creatinine clearance $(\mathrm{CrCl})$ of $43.4 \mathrm{ml} / \mathrm{min}$ using the modified Cockcroft-Gault equation. She was admitted for further workup. A trial of IV fluid hydration overnight worsened her symptoms and additional labs demonstrated hypoalbuminemia, 4+ proteinuria with $1+$ blood, and a urine protein/creatinine ratio of $17 \mathrm{mg} /$ $\mathrm{mg}(<0.2 \mathrm{mg} / \mathrm{mg})$, consistent with nephrotic syndrome. Her CD4 count was 115 cells/mm3 (500-1500 cells/ mm3) with an HIV viral load of 117,148 copies/ml. Based off negative labs for syphilis, hepatitis panel, ANA, complement $\mathrm{C} 3 / \mathrm{C} 4$, and diabetes, findings were felt to be consistent with HIV Associated Nephropathy (HIVAN).
The patient underwent renal biopsy to confirm the diagnosis and was started on abacavir, darunavir, dolutegravir, lamivudine and ritonavir. Pathology results were consistent with HIVAN with tubulointerstitial nephritis and collapsing glomerulonephropathy and electron microscopy showed diffuse epithelial cell injury with effacement of foot processes and segmental collapse of glomerular capillary loops. Her serum $\mathrm{Cr}$ peaked at 2.78 on day 7 of her admission. Her serum $\mathrm{Cr}$ and urea-nitrogen steadily improved after just one week of HAART therapy leading to a $42 \%$ reduction in serum $\mathrm{Cr}$ (Figure 1). Additionally, due to her un-resolving dysphagia the patient underwent esophagogastroduodenoscopy, which was unremarkable. However, she subsequently had esophageal manometry, which was consistent with diffuse esophageal spasm for which she was started on diltiazem.

\section{DISCUSSION}

HIV-associated nephropathy (HIVAN) is an aggressive form of collapsing focal segmental glomerulosclerosis and tubulointerstitial lesions that is observed predominantly in African Americans. The first descriptions of this disease manifestation were among African-American and Haitian immigrants with advanced HIV illness, which serve to highlight the racial disparity and genetic susceptibility to HIVAN. ${ }^{1}$ The era of highly active antiretroviral therapy (HAART) has reduced the incidence of HIVAN; however, HIVAN remains the 3rd leading cause of end stage renal disease (ESRD) among blacks between the ages of 20-64 years old, with an estimated $90 \%$ of patients with ESRD attributed to HIVAN being of AfricanAmerican descent. ${ }^{2}$ Although incompletely understood it has been postulated that the pathogenesis of HIVAN involves several factors, including direct HIV infection of glomerular and tubular epithelial cells and upregulation of host cellular pathways involved in apoptosis and cell cycle arrest. ${ }^{3-5}$ As previously mentioned, current therapy involves initiation of HAART, along with renal replacement therapy and renin-angiotensin system inhibitors as warranted. 


\section{Trend of serum creatinine $(\mathrm{Cr})$ and serum urea-nitrogen}



Figure 1. Trend of serum creatinine $(\mathrm{Cr})$ (normal range: $0.7-1.3 \mathrm{mg} / \mathrm{dL}$ ) and serum urea-nitrogen $(\mathrm{mg} / \mathrm{dL})$ (normal range: $8-20 \mathrm{mg} / \mathrm{dL}$ ) since presentation to the ED (day 0 ) across time (days).

Ultimately, HIV prevention remains the best approach to impact the epidemiology of HIVAN. In this case report, it was not clear for exactly how long the patient had HIV, however if it was a recent transmission it would have been a rare case of HIVAN in the setting of sub-acute HIV infection. Additional high quality studies and randomized clinical trials are needed to establish treatment beyond HAART for HIVAN, taking into account the recent progress in the understanding of the pathogenesis of HIVAN in the existing body of literature. Furthermore, it is still not clear which of the combination antiretroviral therapies (cART) available are effective in treating HIVAN and to what extent they are achieving survival and morbidity reductions.

\section{SUMMARY}

This case serves as an example of an uncommon yet dangerous complication of HIV. In the setting of nephrotic syndrome, screening for HIV infection and ruling out HIVAN in HIV-infected individuals is essential. HIVAN may be the first manifestation of HIV-1 infection in an otherwise asymptomatic patient and preservation of renal function in African Americans with chronic kidney disease and HIV is dependent upon its prompt recognition and early treatment. Early recognition and treatment of HIVAN has the potential to delay the onset of ESRD and improve mortality associated with complications of HIV.

\section{REFERENCES}

1. Wyatt CM, Klotman PE, D'Agati VD. 2008. HIV-associated nephropathy: clinical presentation, pathology, and epidemiology in the era of antiretroviral therapy. Semin. Nephrol. 28(6):513-22

2. United States Renal Data System. 2010. USRDS 2010 Annual Data Report: Atlas of Chronic Kidney Disease and End-Stage Renal Disease in the United States. http://www.usrds.org/adr.htm

3. Rosenstiel P, Gharavi A, D'Agati V, et al. 2009. Transgenic and infectious animal models of HIV associated nephropathy. J. Am. Soc. Nephrol. 20(11):2296-304

4. Bruggeman LA, Ross MD, Tanji N, et al. Renal epithelium is a previously unrecognized site of HIV-1 infection. J Am SocNephrol 2000; 11:2079

5. Ross MJ, Bruggeman LA, Wilson PD, Klotman PE.Microcyst formation and HIVB-1 gene expression occur in multiple nephron segments in HIV-associated nephropathy. J Am SocNephrol 2001; $12: 2645$ 